Article

\title{
Influence of Froth Height on Column Flotation of Kaolin Ore
}

\author{
Fernando Pita ${ }^{1,2}$ \\ 1 Geosciences Centre, Department of Earth Sciences, Faculty of Sciences and Technology, \\ University of Coimbra, 3030-790 Coimbra, Portugal; fpita@ci.uc.pt; Tel.: +351-239-860-500 \\ 2 Centre for Mechanical Engineering, Materials and Processes, Faculty of Sciences and Technology, \\ University of Coimbra, 3030-788 Coimbra, Portugal
}

Received: 17 October 2017; Accepted: 22 November 2017; Published: 26 November 2017

\begin{abstract}
The influence of the froth height in the reverse flotation of kaolinitic ore was analyzed based on the recovery by entrainment and by true flotation of iron, titanium and manganese oxides $\left(\mathrm{FeO}, \mathrm{TiO}_{2}\right.$ and $\left.\mathrm{MnO}\right)$. Also, the influence of the particle size in the drainage process was analyzed. The recovery by entrainment and by true flotation of the three oxides is inversely proportional to the froth height. The entrained particles are drained more easily in the froth phase than the floated particles since they are not attached to the bubbles. The recovery by entrainment and drainage of the entrained material is similar for the three oxides. However, the recovery by true flotation and drainage of the floated material is different for the three oxides. FeO has the lowest recovery, as a consequence of the minor contribution of its hydrophobic minerals, while $\mathrm{MnO}$ has the greatest recovery values. For the entrained material, the finest fraction is entrained more easily, but it is also drained more easily, meaning these particles have more mobility in the froth zone. For the true floated material, the finest fraction is drained more easily, indicating the greater mobility of these particles in the froth; however, the coarsest fraction is drained more easily than the two intermediate fractions, indicating the weaker attachment of the larger particles to the bubbles.
\end{abstract}

Keywords: flotation; froth height; entrainment; true flotation; particle size

\section{Introduction}

Froth flotation is the most important and versatile separation method used in the mining industry. It is a physical-chemical process based on the selective adhesion of certain particles to the air (hydrophobic particles) or the water (hydrophilic particles). The flotation process can be divided into two distinct phases: one that takes place in the pulp zone (collection zone) and the other in the froth zone (drainage zone). A successfully flotation process implies the collision of particles with air bubbles and the formation of particle-bubble aggregates in the pulp zone, and the drainage of the entrained particles in the froth zone, leading to an enrichment of the floated material. During this process, the hydrophobic mineral particles enter into the froth zone attached to the surface of bubbles (true flotation), but the hydrophilic and some hydrophobic mineral particles may enter into the froth as well.

True flotation is a selective phenomenon contributing to the separation of hydrophobic from hydrophilic minerals, while entrainment is a problem in flotation because it is non-selective. Entrainment is responsible for the recovery of hydrophilic particles, especially the finer ones. A successful flotation process involves minimization of the entrainment and maximization of the true flotation.

Entrainment is fundamentally conditioned by the operative conditions (pulp dilution, agitation intensity, aeration rate, stability, and height of the froth) and the nature of the material (density, size, and shape). The recovery by entrainment decreases with the increased dilution of the pulp and 
the froth height, and increases with increased agitation, rate of aeration, and froth stability [1-4]. Also, it decreases with increasing particle size and its density, and depends on the particle shape, with lamellar shape particles being more easily entrained [5-10]. A large number of studies have shown that entrainment recovery is proportional to water recovery $[5,7,8,11]$.

The froth is crucial in the flotation process. It can affect both the recovery and the grade, because it promotes the selective drainage of minerals back to the pulp zone. In spite of the separation between the hydrophobic and the hydrophilic particles that takes place in the pulp zone (collection zone), drainage in the froth zone contributes significantly to the increase of selectivity of the flotation process. Therefore, the froth should have enough stability and height, in order to allow the drainage of the entrained hydrophilic particles back into the pulp and, simultaneously support the hydrophobic particles, inhibiting their drainage and contributing to the total selectivity of the process.

Drainage is conditioned by the stability and height of the froth and by the particles' characteristics (size, density, shape, and hydrophobicity). Froth stability depends on several factors: type and concentration of froth, particle size, solid concentration, hydrophobicity, shape and roughness of particles, and air flow rate [12-17].

The probability of the floated and entrained hydrophilic particles dropping back into the pulp zone (drained) is greater when the froth zone is higher, since the retention time is longer. Many authors, including Neethling, Alexander et al., Ross, Schwarz and Grano, and Massinaei et al. [9,15,18-20] studied the influence of the froth height in flotation. They found a strong dependence of the amount of hydrophilic particles drained from the froth on the froth residence time. It was observed that the recovery decreases with the increase in froth height, with the grade of the floated product varying in the opposite direction. It seems that the drainage of the entrained particles is more intense than the drainage of the floated particles. However, the drainage is not constant along the height of the froth, being more pronounced near the pulp-froth interface, where the percentage of water is larger $[13,18,20]$. In unstable and thick froth, although the drainage is intense and contributes to selective separations, the recoveries are small. Stable and thin froths lead to larger recoveries, but worse separations since the entrained hydrophilic particles are less drained. Froths with proper stabilities are essential in the achievement of good grades and high recoveries.

However, a study by Martínez-Carrillo and Uribe-Salas [21] on the recovery of hydrophilic silica fines in column flotation tests concluded that the entrainment of hydrophilic fines is not affected by froth height (within a range of 10 to $30 \mathrm{~cm}$ ) when wash water is not used. Indeed, Falutsu and Dobby [22] have developed a column that isolates the froth zone from the collection zone, allowing the direct measurement of the recovery obtained in each zone and simultaneously the measurement of the drained material percentage. These authors verified that the recovery in the froth zone was not influenced by the froth height. The injection of wash water at the pulp-froth interface can produce an intense drainage of the entrained material, leading to a froth zone composed of particles strongly attached to the bubbles.

The drainage intensity is affected by the size and density of the particles and by the stability of the particle-bubble aggregates. In the floated hydrophobic material, it is more difficult to drain particles with fine size and low density. However, Alexander et al. [15] suggested that the froth is non-selective in terms of attached particles, i.e., that particles do not break their bonds with air bubbles in the froth phase due to their hydrophobicity, but rather that the dropping back of particles to the pulp phase is caused by bubble breakage and coalescence.

In the entrained material, the effect of particle size on the drainage is conditioned by the stability of the froth. In stable froth, fine particles are drained more easily than coarse particles. In unstable froth, coarse particles are more easily drained than fine particles. In spite of this, Stevenson et al. [23] found that the transport of gangue (entrained) through froth is independent of particle size. So, the greater recovery of the finer particles in the concentrate could be due to physical processes occurring in the pulp zone rather than the froth zone. 
Froth zone recovery is the fraction of material that enters the froth and is transferred to the concentrate. Savassi et al. [24] gave a definition of froth zone recovery $\left(R_{f}\right)$ as the quotient between the mass rate of particles joining the floated material and the mass rate of particles at the pulp-froth interface.

Direct measurement of froth zone recovery is problematic. Several techniques are available to determine froth zone recovery, falling predominantly into two categories: (a) the use of indirect methods that relate froth zone recovery to the first-order flotation rate constants $[14,17,19,25]$; and (b) the estimation or direct measurement of bubble loading below the pulp-froth interface $[15,22,24,26-28]$.

The aims of the present study are: (1) to test and evaluate the influence of the froth height in column flotation tests, using kaolin ore; (2) to analyze the influence of the particle size in the drainage phenomena, in terms of entrainment and true flotation.

This paper presents a methodology for the indirect estimation of froth zone recovery based on the measurement of the effect of froth height on flotation recovery, with the assumption that the froth zone recovery tends towards $100 \%$ when the froth height tends towards zero.

\section{Materials and Methods}

\subsection{Materials}

Batch flotation tests were carried out in a column flotation, for mineral processing of kaolin by reverse froth flotation, in order to float quartz, goethite, ilmenite, rutile and tourmaline, the main penalty minerals of kaolin. In this case, the floated product concentrates the impurities and the tailings (sunk) is the improved kaolin. The kaolin samples were obtained from Caulicentro Mine in Lousã-Coimbra, Portugal. In that mine, a combination of wet screening and hydrocycloning is used to process the kaolin ore. In the laboratory, the kaolin samples were dried and disaggregated for use in the flotation tests.

To analyze the effect of the particle size on the flotation process, the size distributions of the concentrate and tailing products were measured by wet sieving, and the following size fractions were obtained: $<25 \mu \mathrm{m} ;+25-45 \mu \mathrm{m},+45-63 \mu \mathrm{m} ;>63 \mu \mathrm{m}$.

The mineralogical composition of the four particle size fractions was identified by electronic microprobe (JEOL JXA 8500F, Freising, Germany) analysis (Table 1). The main minerals are kaolinite, quartz, feldspar, and muscovite. While kaolinite predominates in the finest fraction, in fractions greater than $25 \mu \mathrm{m}$ quartz is the predominant mineral, followed by feldspar and muscovite.

Table 1. Kaolin ore minerals, measured by electronic microprobe (\%).

\begin{tabular}{ccccc}
\hline \multirow{2}{*}{ Minerals } & \multicolumn{4}{c}{ Size Fractions $(\boldsymbol{\mu m})$} \\
\cline { 2 - 5 } & $\mathbf{< 2 5}$ & $\mathbf{2 5 - 4 5}$ & $\mathbf{4 5 - 6 3}$ & $>\mathbf{6 3}$ \\
\hline Kaolinite & 73.8 & 9.3 & 3.6 & 1.4 \\
Quartz & 14.8 & 56.3 & 58.1 & 79.1 \\
Feldspar & 6.4 & 21.8 & 26.5 & 13.1 \\
Muscovite & 1.1 & 7.1 & 7.1 & 3.5 \\
Goethite & 0.4 & 0.8 & 0.8 & 0.6 \\
Hydrated aluminium silicate & 1.0 & 1.0 & 1.1 & 0.8 \\
Iron aluminosilicate & 1.8 & 1.5 & 1.0 & 0.4 \\
Ilmenite & 0.4 & 0.9 & 0.5 & 0.3 \\
Rutile & 0.2 & 0.5 & 0.3 & 0.1 \\
Tourmaline & 0.1 & 0.8 & 1.0 & 0.7 \\
\hline
\end{tabular}

Because the study was based on the recovery of iron, titanium, and manganese oxides $\left(\mathrm{FeO}, \mathrm{TiO}_{2}\right.$ and $\mathrm{MnO}$ ) and not on the mineral recovery, it was necessary to determine the contribution of each oxide to the kaolin ore minerals (Table 2). 
Table 2. Distribution of $\mathrm{FeO}, \mathrm{TiO}_{2}$, and $\mathrm{MnO}(\%)$ in minerals, measured by electronic microprobe.

\begin{tabular}{|c|c|c|c|c|c|c|c|c|c|c|c|c|}
\hline \multirow{2}{*}{ Minerals } & \multicolumn{4}{|c|}{ FeO (\% Weight) } & \multicolumn{4}{|c|}{$\mathrm{TiO}_{2}$ (\% Weight) } & \multicolumn{4}{|c|}{ MnO (\% Weight) } \\
\hline & $<25$ & $25-45$ & $45-63$ & $>63$ & $<25$ & $25-45$ & $45-63$ & $>63$ & $<25$ & $25-45$ & $45-63$ & $>63$ \\
\hline Kaolinite & 49.8 & 7.2 & 3.5 & 2.6 & 48.1 & 3.6 & 2.8 & 2.2 & 40.8 & 2.4 & 1.3 & 0.7 \\
\hline Feldspar & 0.1 & 0.6 & 0.9 & 0.8 & 0.5 & 0.9 & 2.3 & 2.4 & 3.6 & 5.5 & 9.7 & 6.9 \\
\hline Muscovite & 0.8 & 5.8 & 7.5 & 6.9 & 0.7 & 2.7 & 5.4 & 5.5 & 0.6 & 1.8 & 2.6 & 1.8 \\
\hline Goethite & 9.3 & 29.5 & 38.0 & 43.1 & 0.1 & 0.1 & 0.3 & 0.3 & 5.0 & 6.3 & 9.2 & 7.9 \\
\hline Ilmenite & 4.5 & 18.4 & 11.0 & 10.3 & 24.3 & 51.8 & 47.7 & 49.3 & 39.6 & 65.5 & 43.9 & 31.3 \\
\hline Rutile & 0.4 & 1.4 & 0.8 & 0.5 & 24.5 & 37.8 & 35.0 & 24.1 & - & - & - & - \\
\hline Tourmaline & - & 3.1 & 8.0 & 8.8 & - & 0.2 & 0.9 & 1.1 & - & 3.8 & 11.0 & 9.2 \\
\hline
\end{tabular}

There are two types of minerals in kaolin ore in terms of floatability: hydrophobic minerals (quartz, goethite, ilmenite, rutile and tourmaline); and hydrophilic minerals (kaolinite, feldspar, muscovite, hydrated aluminium silicate and aluminosilicates). The degree of hydrophobicity of the minerals was not determined (for example, by measuring the contact angle). However, the analysis of the floated material by electronic microprobe, using only one of the tests, allowed us to verify a higher content of quartz, ilmenite, goethite, rutile and tourmaline in the concentrate. The percentage of each oxide in the kaolin minerals determined by electronic microprobe was then combined into hydrophobic and hydrophilic minerals (Table 3).

Table 3. Distribution of $\mathrm{FeO}, \mathrm{TiO}_{2}$, and $\mathrm{MnO}(\%)$ in hydrophobic and hydrophilic minerals.

\begin{tabular}{cccccc}
\hline \multirow{2}{*}{ Oxide } & \multirow{2}{*}{ Mineral Type } & \multicolumn{4}{c}{ Size Fractions $(\boldsymbol{\mu m})$} \\
\cline { 3 - 6 } & & $\mathbf{< 2 5}$ & $\mathbf{2 5 - 4 5}$ & $\mathbf{4 5 - 6 3}$ & \multicolumn{2}{c}{$\mathbf{6 3}$} \\
\hline \multirow{2}{*}{$\mathrm{FeO}$} & Hydrophobic minerals & 14.5 & 53.8 & 59.7 & 67.6 \\
& Hydrophilic minerals & 85.5 & 46.2 & 40.3 & 32.4 \\
\hline \multirow{2}{*}{$\mathrm{TiO}_{2}$} & Hydrophobic minerals & 50.0 & 92.4 & 89.0 & 89.3 \\
& Hydrophilic minerals & 50.0 & 7.6 & 11.0 & 10.7 \\
\hline \multirow{2}{*}{$\mathrm{MnO}$} & Hydrophobic minerals & 52.9 & 89.5 & 85.2 & 89.8 \\
& Hydrophilic minerals & 47.1 & 10.5 & 14.8 & 10.2 \\
\hline
\end{tabular}

In the size fraction lower than $25 \mu \mathrm{m}$ only $15 \%$ of $\mathrm{FeO}$ and about $50 \%$ of $\mathrm{TiO}_{2}$ and $\mathrm{MnO}$ come from the hydrophobic minerals. The hydrophobic minerals contribute more of the three oxides in the three coarser fractions, contributing nearly $60 \%$ of those minerals for $\mathrm{FeO}$ and about $90 \%$ for the other two oxides (Table 3).

The particle size distribution of the kaolin ore and the grade of the three oxides in four size fractions determined by AAS (atomic absorption spectrometry, Solaar M2 Thermo Scientific, Cambridge, MA, USA) are presented in Table 4.

Table 4. Particle size and grades of $\mathrm{FeO}, \mathrm{TiO}_{2}$, and $\mathrm{MnO}$ in four size fractions.

\begin{tabular}{ccccc}
\hline Size Fractions & Weight & \multicolumn{3}{c}{ Grade of Oxide (\%) } \\
\hline $\mathbf{( \mu \mathbf { m } )}$ & $\mathbf{( \% )}$ & $\mathbf{F e O}$ & $\mathrm{TiO}_{\mathbf{2}}$ & $\mathbf{M n O}$ \\
\hline$<25$ & 96.27 & 1.902 & 0.397 & 0.010 \\
$25-45$ & 1.66 & 0.861 & 0.504 & 0.061 \\
$45-63$ & 0.68 & 0.704 & 0.366 & 0.049 \\
$>63$ & 1.39 & 0.763 & 0.300 & 0.024 \\
\hline
\end{tabular}




\subsection{Flotation Experiments}

The column flotation has a height of $3.40 \mathrm{~m}$ and a diameter of $7.2 \mathrm{~cm}$ and was operated with the recycling of the tailings in a closed circuit. The column is made of acrylic material and porous discs have $0.5 \mathrm{~mm}$ pore size. The froth height varied between 6 and $35 \mathrm{~cm}$, systematically with a near $5 \mathrm{~cm}$ increment. No wash water was used in order to maintain the stable chemical conditions and enable the operation of the column for a longer period of time.

The optimum working conditions, i.e., those that would produce a more enriched concentrate and a more impoverished tailings (processed kaolin) in penalty minerals, were determined in the planning of experimental tests. After performing multiple tests altering the operating conditions, the reagents and conditions that provided the best results were: concentration of solids in the pulp: $17.5 \%$; $\mathrm{pH}$ of the pulp: adjusted to around 9.5 by adding sodium hydroxide; sodium silicate (dispersant) was added at a dosage of $1.2 \mathrm{~kg} /$ ton and the pulp was conditioned for $5 \mathrm{~min}$; then kerosene activator was added at a dosage of $0.5 \mathrm{~kg} /$ ton and conditioned during $2 \mathrm{~min}$; next oleic acid collector was added, at a dosage of $2 \mathrm{~kg} /$ ton, and conditioned during $5 \mathrm{~min}$; after $2 \mathrm{~min}$ of froth conditioning (Cyanamid aerofroth 65) with dosage of $30 \times 10^{-3} \mathrm{~g} / \mathrm{L}$ air was introduced. After performing flotation tests at three aeration rates $(2.4,3.6$ and $4.8 \mathrm{~L} / \mathrm{min})$, it was verified that the aeration rate of $3.6 \mathrm{~L}^{3} / \mathrm{min}$ led to the highest recovery of the three oxides in the floated material. In the present study, the aeration rate used was $3.6 \mathrm{~L} / \mathrm{min}$. All reagents used in the experiments were chemically pure and were obtained from Chem-Lab Company (Zedelgem, Belgium). The experiments were carried out at room temperature and tap water was used in all tests. The tests were performed three times under similar operating conditions and the coefficients of variation were less than 0.05 .

The flotation tests were carried out for $8 \mathrm{~min}$. Size distributions of four fractions $(<25 \mu \mathrm{m}$; $+25-45 \mu \mathrm{m},+45-63 \mu \mathrm{m} ;>63 \mu \mathrm{m})$ were determined in the concentrate and tailing products by wet sieving. For all fractions, the chemical assays in $\mathrm{FeO}, \mathrm{TiO}_{2}$, and $\mathrm{MnO}$ were determined by atomic absorption spectrometry. The results were compared against the percentage of each oxide in the kaolin minerals determined by electronic microprobe.

Since the influence of froth height may be different in the entrained and floated materials, the effect of the froth height in the recovery by entrainment and by true flotation is analyzed separately, giving more precise information about the effect of the froth height in both processes. The total recovery was not considered because its behaviour can be masked by those two types of recoveries. The recovery by true flotation and by entrainment of the three oxides was quantified by the method of Ross and Van Deventer [29].

\section{Results and Discussion}

Recovery of $\mathrm{FeO}, \mathrm{TiO}_{2}$, and $\mathrm{MnO}$ by true flotation (TF) and by entrainment (ENT) after 8 min is given as a function of froth height for different size fractions (Figure 1). Water recovery is also presented for comparison (Figure 1).

Froth height has a significant effect on the recovery of the three oxides, as well as on the water recovery. Recovery by entrainment, by true flotation and water recovery decreases with increasing froth height. That is attributed to a longer froth retention time, which leads to an increased drainage time.

True flotation is more effective for coarse particles, but entrainment recovery increases with decreasing particle size, being more visible for the finer size fraction. Since the finer fraction weighs $96 \%$ of the total sample of kaolin ore (Table 4), this feature plays an important role in the flotation process.

The entrainment results are similar for the three oxides, which illustrates the non-selectivity of the entrainment, being independent of the mineral species. However, $\mathrm{FeO}$ shows a slightly greater value for entrainment. $\mathrm{FeO}$ has the lowest recovery by true flotation, as a consequence of the minor contribution of its hydrophobic minerals, making this oxide more susceptible to being entrained.

The recovery by entrainment of the three oxides decreases with decreasing water recovery for all size fractions (Figure 1). The entrainment recovery, in all size fractions, is less than the corresponding water recovery, although the recovery of the finer size fraction (i.e., under $25 \mu \mathrm{m}$ ) closely approaches 
the water recovery value. These results are comparable to those of most of the previous works on this subject, taking into account the water recovery range and the particles size studied [5-9,21].
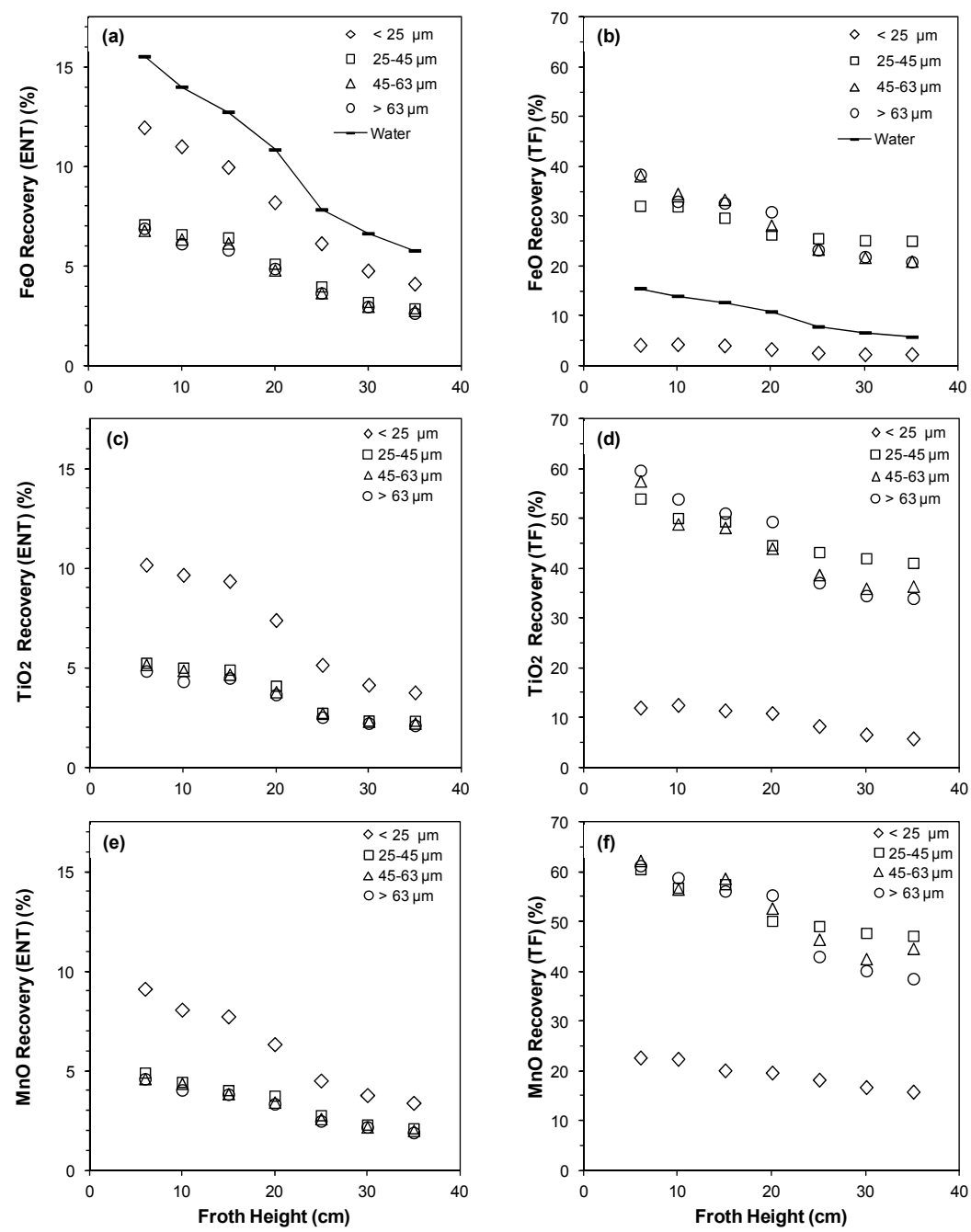

Figure 1. Effect of froth height on the water recovery $(a, b)$ and on the recovery by entrainment (ENT) of iron (a), titanium (c) and manganese (e) oxides and on the recovery by true flotation (TF) of iron (b), titanium (d) and manganese (f) oxides, in four size fractions.

As expected, the recovery by true flotation is generally greater than the recovery by entrainment, with the exception of the finer fraction of the $\mathrm{FeO}$.

For all size fractions, $\mathrm{MnO}$ presents the greatest recovery by true flotation, a consequence of the largest contribution of the hydrophobic minerals in this oxide (Table 3). FeO has the lowest recovery values, as a result of the smallest contribution of the hydrophobic minerals (Table 3), while $\mathrm{TiO}_{2}$ recovery presents intermediate values. Since $\mathrm{TiO}_{2}$ and $\mathrm{MnO}$ have similar contributions of hydrophobic minerals (Table 3), the worse recovery of $\mathrm{TiO}_{2}$ may be due to the lower hydrophobicity of rutile versus ilmenite and quartz (Table 2). Less significant recovery of the three oxides by true flotation is observed for the size fraction lower than $25 \mu \mathrm{m}$, an outcome of the smaller contribution of hydrophobic minerals and of the particle size.

Regression analyses (linear, logarithmic, cubic, power and exponential) of the recovery results versus froth height were made for all size fractions, and the goodness of fit and their statistical significance calculated. The best results were obtained when a linear model was used. The goodness of fit was measured by the $\mathrm{F}$ test and the significance levels were generally up to 0.001 . 
A linear equation of the following form was used:

$$
R=a+b \times h
$$

where $R$ is the recovery at the end of the flotation test; $h$ is the froth height; $a$ is the $y$-intercept; and $b$ is the slope of the linear regression line.

For all linear regressions, the R-squared $\left(R^{2}\right)$ presents high values and the significance level presents low values, giving reliability to the influence of the froth height in the recovery by entrainment and by true flotation of the three oxides. The goodness of fitting of the $\mathrm{FeO}, \mathrm{TiO}_{2}$ and $\mathrm{MnO}$ recovery versus froth height revealed linear regressions with correlation coefficients significant at the 0.001 level (Table 5).

Table 5. Linear regression coefficients ( $a$ and $b$ ), critical froth heights $\left(h_{c}\right)$, Standard error associated with the calculation of the slope and the intercept of the curve between parentheses, $\mathrm{R}$-squared $\left(R^{2}\right)$ and significance levels * of the oxides recovery by entrainment and true flotation of the four size fractions.

\begin{tabular}{|c|c|c|c|c|c|c|c|c|c|}
\hline \multirow{2}{*}{ Oxide } & \multirow{2}{*}{$\begin{array}{c}\text { Fraction } \\
(\mu \mathrm{m})\end{array}$} & \multicolumn{4}{|c|}{ Entrainment } & \multicolumn{4}{|c|}{ True Flotation } \\
\hline & & $a$ & $b$ & $h_{c}(\mathrm{~cm})$ & $\mathbf{R}^{2}$ & $A$ & $b$ & $h_{c}(\mathrm{~cm})$ & $\mathbf{R}^{2}$ \\
\hline \multirow{4}{*}{$\mathrm{FeO}$} & $<25$ & $\begin{array}{l}13.89 \\
(0.34)\end{array}$ & $\begin{array}{l}-0.291 \\
(0.015)\end{array}$ & 47.7 & $0.986^{*}$ & $\begin{array}{c}4.91 \\
(0.251)\end{array}$ & $\begin{array}{l}-0.082 \\
(0.082)\end{array}$ & 59.9 & 0.913 * \\
\hline & $25-45$ & $\begin{array}{c}8.26 \\
(0.29)\end{array}$ & $\begin{array}{l}-0.160 \\
(0.013)\end{array}$ & 51.6 & 0.968 * & $\begin{array}{l}33.68 \\
(1.02)\end{array}$ & $\begin{array}{l}-0.283 \\
(0.046)\end{array}$ & 119.0 & $0.885^{* *}$ \\
\hline & $45-63$ & $\begin{array}{c}7.92 \\
(0.31)\end{array}$ & $\begin{array}{l}-0.156 \\
(0.014)\end{array}$ & 50.8 & $0.961 *$ & $\begin{array}{l}41.20 \\
(1.30)\end{array}$ & $\begin{array}{l}-0.595 \\
(0.058)\end{array}$ & 69.2 & 0.960 * \\
\hline & $>63$ & $\begin{array}{c}7.83 \\
(0.22)\end{array}$ & $\begin{array}{l}-0.155 \\
(0.010)\end{array}$ & 50.5 & 0.980 * & $\begin{array}{l}41.06 \\
(1.64)\end{array}$ & $\begin{array}{c}-0.614 \\
(0.074)\end{array}$ & 66.8 & 0.933 * \\
\hline \multirow{4}{*}{$\mathrm{TiO}_{2}$} & $<25$ & $\begin{array}{l}12.18 \\
(0.56)\end{array}$ & $\begin{array}{l}-0.252 \\
(0.025)\end{array}$ & 48.3 & $0.952 *$ & $\begin{array}{l}14.64 \\
(0.74)\end{array}$ & $\begin{array}{l}-0.247 \\
(0.033)\end{array}$ & 59.3 & $0.918^{*}$ \\
\hline & $25-45$ & $\begin{array}{c}6.21 \\
(0.34)\end{array}$ & $\begin{array}{l}-0.119 \\
(0.015)\end{array}$ & 52.2 & $0.923 *$ & $\begin{array}{l}55.29 \\
(1.55)\end{array}$ & $\begin{array}{l}-0.444 \\
(0.051)\end{array}$ & 124.5 & 0.937 * \\
\hline & $45-63$ & $\begin{array}{c}6.02 \\
(0.26)\end{array}$ & $\begin{array}{l}-0.116 \\
(0.012)\end{array}$ & 51.9 & 0.950 * & $\begin{array}{l}59.68 \\
(2.13)\end{array}$ & $\begin{array}{l}-0.716 \\
(0.095)\end{array}$ & 83.4 & 0.919 * \\
\hline & $>63$ & $\begin{array}{c}5.57 \\
(0.29)\end{array}$ & $\begin{array}{l}-0.105 \\
(0.013)\end{array}$ & 53.0 & $0.925 *$ & $\begin{array}{l}64.74 \\
(2.44)\end{array}$ & $\begin{array}{c}-0.947 \\
0.109)\end{array}$ & 68.4 & 0.938 * \\
\hline \multirow{4}{*}{$\mathrm{MnO}$} & $<25$ & $\begin{array}{l}10.41 \\
(0.37)\end{array}$ & $\begin{array}{l}-0.212 \\
(0.016)\end{array}$ & 49.1 & 0.970 * & $\begin{array}{l}24.38 \\
(0.33)\end{array}$ & $\begin{array}{l}-0.247 \\
(0.014)\end{array}$ & 98.7 & $0.982 *$ \\
\hline & $25-45$ & $\begin{array}{c}5.53 \\
(0.16)\end{array}$ & $\begin{array}{l}-0.102 \\
(0.007)\end{array}$ & 54.2 & $0.976^{*}$ & $\begin{array}{l}62.51 \\
(1.64)\end{array}$ & $\begin{array}{l}-0.466 \\
(0.073)\end{array}$ & 134.1 & 0.897 * \\
\hline & $45-63$ & $\begin{array}{c}5.28 \\
(0.13)\end{array}$ & $\begin{array}{l}-0.098 \\
(0.006)\end{array}$ & 53.9 & $0.981 *$ & $\begin{array}{l}65.66 \\
(2.34)\end{array}$ & $\begin{array}{c}-0.679 \\
(0.0104)\end{array}$ & 96.7 & 0.894 * \\
\hline & $>63$ & $\begin{array}{c}5.14 \\
(0.14)\end{array}$ & $\begin{array}{l}-0.096 \\
(0.006)\end{array}$ & 53.5 & 0.978 * & $\begin{array}{l}67.95 \\
(2.48)\end{array}$ & $\begin{array}{c}-0.868 \\
(0.111)\end{array}$ & 78.3 & $0.925^{*}$ \\
\hline
\end{tabular}

* Significance level of $0.001 ; * *$ significance level of 0.002 .

From Equation (1) it appears that the phenomenon that takes place in the pulp zone produces effects mostly at intercept $a$ (when the froth height is null the recovery tends to be the collection zone recovery), and the phenomenon that takes place in the froth zone (drainage) influences the magnitude of slope $b$.

The recovery becomes null for a certain froth height, known as the critical froth height $\left(h_{c}\right)$, which can be determined by the relationship between the y-intercept and the absolute value of the slope $\left(h_{c}=a / b\right)$. For values of froth height greater than $h_{c}$, all the material transferred from the pulp zone to the froth zone is drained, and there is no output of the floated material. Therefore, the higher the values of $h_{c}$ the lower the probability of drainage.

Linear regression coefficients and critical froth heights obtained from experimental data concerning the recovery of the $\mathrm{FeO}, \mathrm{TiO}_{2}$ and $\mathrm{MnO}$ in the four size fractions are presented in Table 5 . 
For recovery by entrainment of the three oxides, the finer fraction $(<25 \mu \mathrm{m})$ has a greater $y$-intercept of the linear regression than coarser fractions (Table 5). Since the $y$-intercept depends only on what happens in the pulp zone, the fine material can be more easily entrained, moving from the pulp zone to the froth zone. In fact, for the three coarser fractions the y-intercept of the linear regression decreases slightly with increasing particle size. These results are in agreement with previous studies by Subrahmanyam and Forssberger [6], Kirjavainen [7], Zheng et al. [8], and Warren [11], in which they concluded that fine particles are more easily entrained.

For recovery by true flotation of the three oxides, a finer size fraction presents a smaller y-intercept (Table 5), meaning lower collection zone recovery as a consequence of the smaller contribution of hydrophobic minerals for the amounts of the three oxides and of the lower probability of collision between fine particles and bubbles. For the three coarse fractions, the regression intercepts (collection zone recovery) increase slightly with increasing particle size (Table 5). Since in this size range, for each oxide, the contribution of hydrophobic minerals is similar (Table 3), this behavior is likely to result from differences in the particle size, increasing the probability of collisions between particles and bubbles. Linear regression of $\mathrm{FeO}$ presents lower y-intercepts than the other two oxides, a consequence of the smaller contribution of the hydrophobic minerals to the $\mathrm{FeO}$ or of their smaller hydrophobicity.

Froth zone recovery is defined as the ratio between the mass of the particles passing from the froth to the floated material and the mass of the particles passing from the pulp to the froth. When the froth height is null, the recovery of solids in the flotation process is merely a result of the collection zone phenomena and the recovery tends to be equal to the collection zone recovery. The estimation of the froth zone recovery $\left(R_{f}\right)$ could be made by changing the froth height, measuring the recovery at each height and extrapolating to zero froth height, in a way that is similar to the Schwarz and Grano method (Equation (2)) [19]:

$$
R_{f}(\%)=\frac{\text { recovery at } h=x(\mathrm{~cm})}{\text { recovery at } h=0(\mathrm{~cm})} \times 100 \%
$$

Based on this assumption, the recovery at $h=0$ could be estimated by the $a$ parameter (the intercept of the recovery versus froth height regression line) and the froth zone recovery $\left(R_{f}\right)$ could be estimated by Equation (2). The drainage (drop back) is estimated by the difference between $100 \%$ and $R_{f}$.

The froth zone recovery and the drop back of the three oxides recovered by entrainment and by true flotation are presented in Tables 6 and 7, respectively. Froth recovery decreases with increasing froth height, whereas the drop back increases with increasing froth height. Small variations in the froth height have a large impact on the froth zone recovery.

Table 6. Froth zone recovery by entrainment of the three different oxides of the four size fractions for four froth heights $(\mathrm{cm})$.

\begin{tabular}{|c|c|c|c|c|c|c|c|c|c|}
\hline \multirow{2}{*}{ Oxide } & \multirow{2}{*}{$\begin{array}{c}\text { Fraction } \\
(\mu \mathrm{m})\end{array}$} & \multicolumn{4}{|c|}{ Froth Zone Recovery (\%) } & \multicolumn{4}{|c|}{ Drop Back (\%) } \\
\hline & & $h=10$ & $h=20$ & $h=30$ & $h=40$ & $h=10$ & $h=20$ & $h=30$ & $h=40$ \\
\hline \multirow{4}{*}{$\mathrm{FeO}$} & $<25$ & 79.0 & 58.1 & 37.1 & 16.2 & 21.0 & 41.9 & 62.9 & 83.8 \\
\hline & $25-45$ & 80.6 & 61.3 & 41.9 & 22.5 & 19.4 & 38.7 & 58.1 & 77.5 \\
\hline & $45-63$ & 80.3 & 60.6 & 40.9 & 21.2 & 19.7 & 39.4 & 59.1 & 78.8 \\
\hline & $>63$ & 80.2 & 60.4 & 40.6 & 20.8 & 19.8 & 39.6 & 59.4 & 79.2 \\
\hline \multirow{4}{*}{$\mathrm{TiO}_{2}$} & $<25$ & 79.3 & 58.6 & 37.9 & 17.2 & 20.7 & 41.4 & 62.1 & 82.8 \\
\hline & $25-45$ & 80.8 & 61.7 & 42.5 & 23.5 & 19.2 & 38.3 & 57.5 & 76.7 \\
\hline & $45-63$ & 80.7 & 61.5 & 42.2 & 22.9 & 19.3 & 38.5 & 57.8 & 77.1 \\
\hline & $>63$ & 81.1 & 62.3 & 43.4 & 24.6 & 18.9 & 37.7 & 56.6 & 75.4 \\
\hline \multirow{4}{*}{$\mathrm{MnO}$} & $<25$ & 79.6 & 59.3 & 38.9 & 18.5 & 20.4 & 40.7 & 61.1 & 81.5 \\
\hline & $25-45$ & 81.6 & 63.1 & 44.7 & 26.2 & 18.4 & 36.9 & 55.3 & 73.8 \\
\hline & $45-63$ & 81.4 & 62.9 & 44.3 & 25.7 & 18.6 & 37.1 & 55.7 & 74.2 \\
\hline & $>63$ & 81.3 & 62.7 & 44.0 & 25.3 & 18.7 & 37.4 & 56.0 & 74.7 \\
\hline
\end{tabular}


Table 7. Froth zone recovery by true flotation of the three different oxides of the four size fractions for four froth heights $(\mathrm{cm})$.

\begin{tabular}{|c|c|c|c|c|c|c|c|c|c|}
\hline \multirow{2}{*}{ Oxide } & \multirow{2}{*}{$\begin{array}{c}\text { Fraction } \\
(\mu \mathrm{m})\end{array}$} & \multicolumn{4}{|c|}{ Froth Zone Recovery (\%) } & \multicolumn{4}{|c|}{ Drop Back (\%) } \\
\hline & & $h=10$ & $h=20$ & $h=30$ & $h=40$ & $h=10$ & $h=20$ & $h=30$ & $h=40$ \\
\hline \multirow{4}{*}{$\mathrm{FeO}$} & $<25$ & 83.3 & 66.6 & 49.9 & 33.2 & 16.7 & 33.4 & 50.1 & 66.8 \\
\hline & $25-45$ & 91.6 & 83.2 & 74.8 & 66.4 & 8.4 & 16.8 & 25.2 & 33.6 \\
\hline & $45-63$ & 85.6 & 71.1 & 56.7 & 42.2 & 14.4 & 28.9 & 43.3 & 57.8 \\
\hline & $>63$ & 85.0 & 70.1 & 55.1 & 40.2 & 15.0 & 29.9 & 44.9 & 59.8 \\
\hline \multirow{4}{*}{$\mathrm{TiO}_{2}$} & $<25$ & 83.1 & 66.3 & 49.4 & 32.5 & 16.9 & 33.7 & 50.6 & 67.5 \\
\hline & $25-45$ & 92.0 & 83.9 & 75.9 & 67.9 & 8.0 & 16.1 & 24.1 & 32.1 \\
\hline & $45-63$ & 88.0 & 76.0 & 64.0 & 52.0 & 12.0 & 24.0 & 36.0 & 48.0 \\
\hline & $>63$ & 85.4 & 70.7 & 56.1 & 41.5 & 14.6 & 29.3 & 43.9 & 58.5 \\
\hline \multirow{4}{*}{$\mathrm{MnO}$} & $<25$ & 89.9 & 79.7 & 69.6 & 59.5 & 10.1 & 20.3 & 30.4 & 40.5 \\
\hline & $25-45$ & 92.5 & 85.1 & 77.6 & 70.2 & 7.5 & 14.9 & 22.4 & 29.8 \\
\hline & $45-63$ & 89.7 & 79.3 & 69.0 & 58.6 & 10.3 & 20.7 & 31.0 & 41.4 \\
\hline & $>63$ & 87.2 & 74.5 & 61.7 & 48.9 & 12.8 & 25.5 & 38.3 & 51.1 \\
\hline
\end{tabular}

Froth zone recovery of the entrained material is similar for the three oxides and is slightly smaller for the finer fraction, indicating an easier drainage of the finer particles through the channels between the bubbles (Table 6).

For the three oxides, the froth zone recovery by true flotation is greater than by entrainment because floated particles are attached to the bubbles. Froth zone recovery of the three oxides by true flotation is different as a consequence of the discriminatory effect on the minerals (Table 7). Froth recovery decreases with increasing froth height, an effect that is more pronounced for iron and titanium oxides. Several authors verified that froth zone recovery decreases as the froth height increases and that it varies with the particle size $[14,17,20,24,26,28,30]$.

For the three oxides, the froth zone recovery by true flotation is smaller for the finer fraction. However, the coarser fraction is more easily drained than the two intermediate fractions. This means that the coarse particles are more weakly attached to the bubbles, a characteristic that overlaps with the entrapment of the coarse particles between the bubbles.

For the coarser fraction, the hydrophobic mineral carriers of manganese oxide are quartz and ilmenite, while in the other three fractions it is ilmenite with minor amounts of quartz (Table 2). A probable lower hydrophobicity of quartz may generate less stable particle-bubble aggregates, and thus justify the easier drainage of the coarser particles.

For the three oxides, the two coarser fractions have greater intercepts indicating greater floatability, but they present smaller froth recoveries than the $25-45 \mu \mathrm{m}$ fraction, indicating low stability of the particle-bubbles aggregates and more intense drainage. The lower drainage of the size fraction $25-45 \mu \mathrm{m}$ (high froth zone recoveries) can be explained by the large contribution of ilmenite (hydrophobic mineral) (Table 2), which leads to the formation of more stable particle-bubble aggregates, which hampers the drainage.

For all size fractions, $\mathrm{MnO}$ presents the greatest froth zone recovery by true flotation, a consequence of the major contribution of its hydrophobic minerals, mainly ilmenite, which hampers its detachment and diminishes drainage. It seems that drainage phenomena are more sensitive to the hydrophobicity of minerals than the collection phenomena that occur in the pulp.

The influence of the particle size on the collision is confirmed by the intercept's increase with increasing particle size in the coarser fractions, where the amount of hydrophobic minerals is similar.

In the pulp zone, the different behavior of titanium and manganese oxides, illustrated by the $y$-intercept, is more evident for the finer fraction (Table 5). Since these two oxides have similar contributions in hydrophobic minerals but a much larger contribution of rutile in the $\mathrm{TiO}_{2}$ and ilmenite in the $\mathrm{MnO}$, it can be argued that the flotation of extremely fine particles is more sensitive to the degree 
of mineral hydrophobicity than the flotation of coarser ones. This behavior may indicate an easier separation of finer particles with respect to coarser ones, because they need higher hydrophobicity in order to float. On the contrary, Trahar [5] found that it was easier to separate coarser particles with small hydrophobic differences than fine particles. Fine particles require lower hydrophobicity to achieve flotation. In addition, Finch and Dobby [1] verified that differences in the collection of two or more minerals that have different attachment times increase with particle size and that the collection efficiency is independent of particle size when the size is less than $5 \mu \mathrm{m}$. However, these assumptions cannot explain why recoveries of $\mathrm{TiO}_{2}$ and $\mathrm{MnO}$ in the finer fraction are different from in the coarser fractions.

Attachment time is defined as the time needed for the attachment of particles to an air bubble. A long attachment time corresponds to weak hydrophobicity or low floatability of minerals, while a short attachment time indicates strong hydrophobicity or high floatability of minerals. Attachment time depends on the nature of the material, such as the mineralogy, density, shape and roughness of the particle; the solution chemistry ( $\mathrm{pH}$, ionic strength, concentrations of reagents, etc.); the bubble size; and the conditioning time.

Attachment time, contact time and particle size are related. For the particle-bubble attachment to occur it is necessary that the particle-bubble contact time be higher than the attachment time. The contact time varies with the motion of particles and bubbles, the hydrodynamic conditions and the particle size, being independent of the degree of hydrophobicity of minerals. However, the attachment time is determined by the chemical surface characteristics of the particles and is changed by the addition of reagents.

In a flotation cell, the particle-bubble contact time decreases with decreasing particle size; however, in a column the contact time (evaluated by the sliding time) increases with decreasing particle size [31].

Assuming that the stability of particle-bubble aggregates is related to the degree of hydrophobicity (and also the attachment time), froth zone recovery can be used as an indicator of the stability of the aggregates and, indirectly, can also be used to evaluate the hydrophobicity and the attachment time.

The froth recoveries calculated in this study point to the possibility that the particle-bubble aggregates of rutile are more unstable than those of ilmenite and quartz, since the froth zone recovery of $\mathrm{TiO}_{2}$ is lower than that of $\mathrm{MnO}$. Rutile is composed of $\mathrm{TiO}_{2}$, while ilmenite has almost equal contributions of $\mathrm{MnO}$ and $\mathrm{TiO}_{2}$ (Table 2). Also, it is probable that rutile has a lower hydrophobicity and a greater attachment time than ilmenite and quartz, requiring greater contact time in order to promote its flotation.

Since the contribution of hydrophobic minerals is similar for $\mathrm{TiO}_{2}$ and $\mathrm{MnO}$ (Table 3), the flotation results should be similar, unless the carrier minerals of each oxide have different attachment times.

The overall results of the $\mathrm{TiO}_{2}$ and $\mathrm{MnO}$ recovery are almost the same for the coarser fractions, but the finer fraction $\mathrm{TiO}_{2}$ gives worse results. Although the contact time is greater in the finer fraction, the $\mathrm{TiO}_{2}$ recoveries are smaller than those of $\mathrm{MnO}$, which is probably a consequence of the need for longer attachment times in the finer particles, especially for the fine particles of rutile.

Several researchers have analyzed the effect of particle size on attachment time. Using five different coal types with a particle size range of approximately $40-500 \mu \mathrm{m}$, Ye and Miller [32] show that the attachment time increases with increasing particle size. Similar observations were also made by Wang et al. [33] and Ozdemir et al. [34] for coal samples.

Experimental results of Yoon and Yordan [35] for quartz particles with sizes between 90 and $400 \mu \mathrm{m}$, and of Albijanic et al. [36] for quartz particles of 147-300 $\mu \mathrm{m}$, suggest that the attachment time increases with increasing particle size. Also, Ye et al. [37] verified that for molybdenite with particle sizes between 50 and $200 \mu \mathrm{m}$, sulfur with particle sizes between 700 and $1500 \mu \mathrm{m}$, and resin with particle sizes between 40 and $500 \mu \mathrm{m}$, the attachment time increases with increasing particle size. This behaviour is ascribed to the displacement of the liquid film on the surface of large particles. Also, Ralston et al. [38] observed that for quartz particles with sizes between 10 and $60 \mu \mathrm{m}$ the 
attachment efficiency increases with decreasing particle size, but for stronger hydrophobic particles the attachment efficiency is less dependent on the particle size.

However, Crawford and Ralston [39] found that the attachment time of quartz particles with a size of $15 \mu \mathrm{m}$ is much greater than size fractions with $46 \mu \mathrm{m}$ and with $99 \mu \mathrm{m}$. Also, Nguyen et al. [40] verified that the attachment time of quartz particles smaller than $80 \mu \mathrm{m}$ increases with decreasing particle size.

In the present study, it seems that fine particles $(<25 \mu \mathrm{m})$ can have an attachment time greater than the coarser fractions, mainly for rutile, a floatable mineral with low hydrophobicity, resulting in a greater difficulty of flotation of the fine fraction, reflected in the lower recoveries of titanium oxide compared to manganese oxide.

\section{Conclusions}

The column flotation tests promoted the flotation of the main penalty hydrophobic minerals of kaolin ore, specially ilmenite, quartz, tourmaline, goethite and rutile, measured by the presence of $\mathrm{FeO}, \mathrm{TiO}_{2}$ and $\mathrm{MnO}$. The separation efficiency of $\mathrm{MnO}$ had better results as a consequence of the major contribution and floatability of its hydrophobic minerals. $\mathrm{TiO}_{2}$ achieved good recovery performances in the coarser fractions, nevertheless, in the finer fraction the recovery was lower than the recovery of $\mathrm{MnO}$, which can be justified by the greater difficulty of floating the rutile, the main carrier mineral of $\mathrm{TiO}_{2}$. The performance of the $\mathrm{FeO}$ in the flotation tests was the lowest as a consequence of the minor contribution of hydrophobic minerals.

The entrainment phenomenon and the drainage of entrained material are independent of the mineralogy. The degree of entrainment depends on the particle size, being greater for fractions lower than $25 \mu \mathrm{m}$, and similar for the other three coarser fractions.

The recoveries by true flotation and by entrainment decrease linearly with the increase of froth height, as an outcome of the increased drainage of particles. The effect of the froth height in drainage depends on how the particles are transferred to the froth, and their size and hydrophobicity, with the entrained particles draining more easily than the floated ones. Floated material has greater froth recovery than entrained material since floated particles are attached to bubbles, which makes them more difficult to drain. Drainage depends on the effect of the particle size on the mobility and the stability of the particle-bubble aggregates. For the three oxides, the finest fraction entrained presents the smallest froth zone recovery as a consequence of the greater mobility of the fine particles in the froth.

For true flotation in the three oxides, the finest fraction presents the smallest froth zone recovery. However, the coarser fraction is more easily drained than the two intermediate fractions. This means that particles of greater size are more weakly attached to the bubbles, a feature that overlaps with the effect of the entrapment of the coarser particles between the bubbles.

The drainage phenomenon is more sensitive to the degree of hydrophobicity than the phenomenon that occurs in the pulp zone for particles greater than $25 \mu \mathrm{m}$. However, for fine particles, the phenomenon that occurred in the pulp zone presents as much or more sensitivity to the degree of hydrophobicity of the particles than the phenomenon that occurred in the froth zone.

Acknowledgments: This work was supported by the Portuguese Foundation for Science and Technology (FCT-MEC) through national funds and, when applicable, co-financed by FEDER in the ambit of the partnership PT2020, through the following research projects: UID/Multi/00073/2013 of the Geosciences Center and UID/EMS/00285/2013 of the Centre for Mechanical Engineering of the University of Coimbra.

Conflicts of Interest: The author declares no conflict of interest.

\section{References}

1. Finch, J.A.; Dobby, G.S. Column Flotation; Pergamon Press: Oxford, UK, 1990.

2. Holtham, P.N.; Cheng, T.-W. Study of probability of detachment of particles from in flotation. Trans. Inst. Min. Metall. Sect. C 1991, 100, C147-C153. 
3. Kawatra, S.K.; Eisele, T.C. Recovery of Pyrite in Coal Flotation: Entrainment or Hydrophobicity? Miner. Metall. Process. 1992, 9, 57-61.

4. Cilek, E.C. The effect of hydrodynamic conditions on true flotation and entrainment in flotation of a complex sulphide ore. Int. J. Miner. Process. 2009, 90, 35-44. [CrossRef]

5. Trahar, W.J. A rational interpretation of the role of particle size in flotation. Int. J. Miner. Process. 1981, 8, 289-327. [CrossRef]

6. Subrahmanyam, T.V.; Forssberg, E.K.S. Froth stability, particle entrainment and drainage in flotation. A Review. Int. J. Miner. Process. 1988, 23, 33-53. [CrossRef]

7. Kirjavainen, V.M. Application of a probability model for for the entrainment of hydrophilic particles in froth flotation. Int. J. Miner. Process. 1989, 27, 63-74. [CrossRef]

8. Zheng, X.; Johnson, N.W.; Franzidis, J.P. Modelling of entrainment in industrial flotation cells: Water recovery and degree of entrainment. Miner. Eng. 2006, 19, 1191-1203. [CrossRef]

9. Neethling, S.J. Simple approximations for estimating froth recovery. Int. J. Miner. Process. 2008, 89, 44-52. [CrossRef]

10. Pita, F.A. True flotation and entrainment of kaolinitic ore in batch tests. Miner. Process. Extr. Metall. Rev. 2015, 36, 213-222. [CrossRef]

11. Warren, L.J. Determination of the contributions of true flotation and entrainment in batch flotation tests. Int. J. Miner. Process. 1985, 14, 33-44. [CrossRef]

12. Szatkowski, M. Factors influencing behaviour of flotation froth. Trans. Inst. Min. Metall. Sect. C 1987, 96, C115-C121.

13. Yianatos, J.B.; Bergh, L.G.; Cortés, G.A. Froth zone modelling of an industrial flotation column. Miner. Eng. 1998, 11, 423-435. [CrossRef]

14. Vera, M.A.; Manlapig, E.V.; Franzidis, J.P. Simultaneous determination of collection zone rate constant and froth zone recovery in a mechanical flotation environment. Miner. Eng. 1999, 12, 1163-1176. [CrossRef]

15. Alexander, D.J.; Franzidis, J.P.; Manlapig, E.V. Froth recovery measurement in plant scale flotation cells. Miner. Eng. 2003, 16, 1197-1203. [CrossRef]

16. Honaker, R.Q.; Ozsever, A.V.; Parekh, B.K. Selective detachment process in column flotation froth. Miner. Eng. 2006, 19, 687-695. [CrossRef]

17. Tsatouhas, G.; Grano, S.R.; Vera, M. Case studies on the performance and characterisation of the froth phase in industrial flotation circuits. Miner. Eng. 2006, 19, 774-783. [CrossRef]

18. Ross, V. An investigation of sub-processes in equilibrium froths. The mechanisms of detachment and drainage. Int. J. Miner. Process. 1991, 31, 37-50. [CrossRef]

19. Schwarz, S.; Grano, S. Effect of particle hydrophobicity on particle and water transport across a flotation froth. Colloid Surf. A. 2005, 256, 157-164. [CrossRef]

20. Massinaei, M.; Kolahdoozan, M.; Noaparast, M.; Oliazadeh, M.; Yianatos, J.; Shamsadini, R.; Yarahmadi, M. Froth zone characterization of an industrial flotation column in rougher circuit. Miner. Eng. 2009, 22, 272-278. [CrossRef]

21. Martínez-Carrillo, D.; Uribe-Salas, A. An experimental study of the recovery of hydrophilic silica fines in column flotation. Miner. Eng. 2008, 21, 1102-1108. [CrossRef]

22. Falutsu, M.; Dobby, G.S. Direct measurement of froth drop back and collection zone recovery in a laboratory flotation column. Miner. Eng. 1989, 2, 377-386. [CrossRef]

23. Stevenson, P.; Ata, S.; Evans, G.M. Convective-dispersive gangue transport in flotation froth. Chem. Eng. Sci. 2007, 62, 5736-5777. [CrossRef]

24. Savassi, O.N.; Alexander, D.J.; Johnson, N.W.; Manlapig, E.V.; Franzidis, J.P. Measurement of froth recovery of attached particles in industrial cells. In Proceedings of the AusIMM Sixth Mill Operators Conference, Mandang, Papua New Guinea, 6-8 October 1997; Volume 99, pp. 149-155.

25. Feteris, S.M.; Frew, J.A.; Jowett, A. Modelling the effect of froth depth in flotation. Int. J. Miner. Process. 1987, 20, 121-135. [CrossRef]

26. Seaman, D.R.; Franzidis, J.P.; Manlapig, E.V. Bubble load measurement in the pulp zone of industrial flotation machines-A new device for determining the froth recovery of attached particles. Int. J. Miner. Process. 2004, 74, 1-13. [CrossRef]

27. Moys, M.H.; Yianatos, J.; Larenas, J. Measurement of particle loading on bubbles in the flotation process. Miner. Eng. 2010, 23, 131-136. [CrossRef] 
28. Rahman, R.M.; Ata, S.; Jameson, G.J. The effect of flotation variables on the recovery of different particle size fraction in the froth and the pulp. Int. J. Miner. Process. 2012, 106-109, 70-77. [CrossRef]

29. Ross, V.; Van Deventer, J.S.J. Mass transport in flotation column froths. In Column Flotation, 88th ed.; Sastry, K.V.S., Ed.; SME Inc.: Littleton, CO, USA, 1988; pp. 129-140.

30. Ata, S. Phenomena in the froth phase of flotation-A review. Int. J. Miner. Process. 2012, 102-103, 1-12. [CrossRef]

31. Dobby, G.S.; Finch, J.A. A model of particle sliding time for flotation sized bubbles. J. Colloid Interface Sci. 1986, 109, 493-498. [CrossRef]

32. Ye, Y.; Miller, J.D. Bubble/particle contact time in the analysis of coal flotation. Coal Prep. 1988, 5, $147-166$. [CrossRef]

33. Wang, W.; Zhou, Z.; Nandakumar, K.; Masliyah, J.H.; Xu, Z. An induction time model for the attachment of an air bubble to a hydrophobic sphere in aqueous solutions. Int. J. Miner. Process. 2005, 75, 69-82. [CrossRef]

34. Ozdemir, O.; Taran, E.; Hampton, M.A.; Karakashev, S.I.; Nguyen, A.V. Surface chemistry aspects of coal flotation in bore water. Int. J. Miner. Process. 2009, 92, 177-183. [CrossRef]

35. Yoon, R.; Yordan, J.L. Induction time measurements for the quartz-amine flotation system. J. Colloid Interface Sci. 1991, 141, 374-383. [CrossRef]

36. Albijanic, B.; Ozdemir, O.; Nguyen, A.V.; Bradshaw, V. A review of induction and attachment times of wetting thin films between air bubbles and particles and its relevance in the separation of particles by flotation. Adv. Colloid Interface Sci. 2010, 159, 1-21. [CrossRef] [PubMed]

37. Ye, Y.; Khandrika, S.M.; Miller, J.D. Induction-time measurements at a particle bed. Int. J. Miner. Process. 1989, 25, 221-240. [CrossRef]

38. Ralston, J.; Fornasiero, D.; Hayes, R. Bubble-particle attachment and detachment in flotation. Int. J. Miner. Process. 1999, 56, 133-164. [CrossRef]

39. Crawford, R.; Ralston, J. The influence of particle size and coxntact angle in mineral flotation. Int. J. Miner. Process. 1988, 23, 1-24. [CrossRef]

40. Nguyen, A.V.; Ralston, J.; Schulze, H.J. On modelling of bubble-particle attachment probability in flotation. Int. J. Miner. Process. 1998, 53, 225-249. [CrossRef] 